U.S. DEPARTYMENTT OF THE INTERIOR

U.S. GEOLOGICAL SURVEY

\title{
GEOLOGIC MAP OF THE LEM PEAK QUADRANGLE,
} LEMHI COUNTY, IDAHO

By R.G. Tysdal 